\title{
How Trust Functions in the Context of Identity Work
}

\author{
By Michaela Driver, Ph.D. \\ Western State Colorado University \\ Department of Business, Accounting \& Economics \\ 221 Borick Business Building \\ Gunnison, Colorado 81231 \\ USA \\ Tel: 970-943-2673 \\ Fax: 970-943-7042 \\ E-mail: mdriver@western.edu
}

\section{Biographical Note:}

Michaela researches alternative and psychoanalytic approaches to a wide range of organizational topics such as organizational identity and learning, emotions, spirituality, corporate social responsibility, identity work, creativity, embodied subjectivity and leadership. Journals in which Michaela’s work has been published include Organization Studies, Human Relations, Organization, Management Learning, Journal of Organizational Change Management, Journal of Business Ethics, and Journal of Management Inquiry. She serves on several editorial boards including Organization Studies, Organization, Management Learning, and the Journal of Management Inquiry. 


\title{
How Trust Functions in the Context of Identity Work
}

\begin{abstract}
The study develops a new perspective on trust in organizations by exploring trust in the context of identity work. An analysis of stories in which employees describe how they experienced when the employer violated their trust suggests that individuals draw on trust discourse to validate who they are. Using a psychoanalytically informed framework, the study examines the complexities of trust in the context of struggles with the conscious self and unconscious desire. Trust emerges as a placeholder for what is really wanted but impossible to attain. Based on this perspective, the study offers new insights on why individuals trust, why trust may be resilient, why trust may be engineered and how trust mirrors identity as an elusive and fleeting accomplishment.
\end{abstract}

Key Words: Trust in Organizations, Trust Violations, Discourse, Identity, Psychoanalysis, Lacan, Storytelling

"From the trust that my employer and I shared, there was a happy and mutually understanding work environment. It was happy because earning trust is an achievement. Being trusted is like being complemented. It allows for a self-reflection saying 'I'm a good person!' and this feels great!" Operations Manager

\section{Introduction}

For over five decades research has explored the vital role of trust in organizations and highlighted its benefits from employee commitment to higher performance (Colquitt et al., 2011; Dirks and Ferrin, 2001; 2002; Fulmer and Gelfand, 2012; Hosmer, 1995). Despite or, as some have argued, because of recent declines in the levels of trust that organizational stakeholders, including employees, are willing to place in organizations today, interest in trust remains high (Sievers, 2003). Commonly defined as a mental state of being willing to be vulnerable to another (Rousseau, Sitkin, Burt and Camerer, 1998), trust has been conceptualized predominantly as a 
rationally evaluative, cognitive process with research focusing on how to understand and improve trust in organizational settings.

In particular, attention has been focused on cues of trustworthiness and how to stimulate “a cycle of growing trust” (Maguire and Phillips, 2008: 376) by enhancing affective attachments between givers and receivers of trust, trustors and trustees respectively (Skinner, Dietz and Weibel, 2014). In view of the latter, identity-based trust has attracted particular attention (Lewicki, Tomlinson and Gillespie, 2006; Maguire and Phillips, 2008; Rousseau et al., 1998). Identity-based trust is considered to be the strongest form of trust and is based on shared identifications between trustors and trustees with the common link between trust and identification being that more identification leads to more trust (Henderson and Gilding, 2004; Maguire and Phillips, 2008; Terrion and Ashforth, 2002; Van der Zee, Vos and Luijters, 2009; Zhand and Huxham, 2009). In other words, what has been examined is how the identification between parties is related to their level of trust.

However, what has not been explored to date is how either trust or identification may be affected by or understood in the context of individual identity work. Maguire and Phillips (2008) investigate how strongly organizational members identify with and therefore trust their organization through stories individuals tell. They treat identity narratives as fragile, sociallyconstructed, linguistic accomplishments but do not explore the identity work of the narrators or how it may affect their organizational trust. It seems that trust research to date has focused on how individuals identify with each other or their institutions but not on how the individual identity required to do so is constructed in the first place. As such, the link between individual identity and identification-based trust seems to have been implied but not further investigated. 
Moreover, while in the organizational literature the link between identification and trust seems to be investigated as moving in one direction, namely that identification leads to trust (Henderson and Gilding, 2004; Maguire and Phillips, 2008; Terrion and Ashforth, 2002; Van der Zee, Vos and Luijters, 2009; Zhand and Huxham, 2009), in other fields a different direction emerges. Specifically, in psychological and sociological writings about individual identity work, trust is also conceived of as a condition for identity. For example, trust in the continuity and comprehensibility of one's world (Adams, 2004: 392) is said to be a vital prerequisite for a sense of identity (Hoegh and Bourgeois, 2002: 590). What has been referred to as generalized trust has been advanced as a condition for self-identity (Groarke, 2002: 561) and the absence of such trust has been found to lead to a corroded sense of self (Webb, 2004: 730).

This study advances the idea that trust may play a similar role in organizations. Organizational trust has been defined already as "a fundamental assumption inherent in most employment relationships...that the employer will operate in a trustworthy manner” (Gillespie and Dietz, 2009: 127). Moreover, trust is said to be related to general perceptions of psychological safety and systemic issues such as perceptions of fairness and the actions of key individuals. Therefore, it seems worth investigating whether organizational trust, like generalized trust (Groarke, 2002: 561), also serves as a condition for identity work in organizations. As one of the respondents for this study cited above suggests, being trusted by one's employer provides a particular "self-reflection" as a "good person", so that trust may function as a resource for constructing certain identities.

To date, employees’ trust in their organization, what I will refer to here as organizational trust, has been theorized as a socially constructed, linguistic, fleeting and ongoing activity (Li, 2011: 16). This seems strikingly similar to how identity has been conceptualized in the 
organizational literature as an elusive, socially and linguistically constructed self (Alvesson, 2010: 203). Yet, the two have not been linked explicitly. The purpose of this study is to explore this link in depth and to do so in particular with regard to the less obvious dynamics of identity work as not only a conscious process but one that is affected by unconscious desires. To this end, I supplement current conceptions of identity with relevant psychoanalytic insights to obtain a more fine-grained perspective on the fragility of both identity and trust and the complexity of their interaction. Drawing on qualitative data collected from over one hundred individuals, the study investigates, in particular, experiences of violations of organizational trust to highlight the link between trust and identity.

The study hopes to make several contributions to the field of organizational trust research. First, the study contributes to research that has been called for to explore in more depth the subjective experience of trust (Dietz, 2011) by investigating what trust means to the narrators who participated in this study and how they feel about it and define it subjectively. Second, the study aims at clarifying the link between trust and identity work in organizations by delving deeper into these subjective experiences and exploring trust as a narrative resource for identity work. Third, the study seeks to offer new insights into the ongoing puzzle about why individuals trust in the first place (Dietz, 2011: 215) by advancing the idea that organizational trust validates but also unsettles identities and thereby serves to fulfill unconscious desire in paradoxical ways.

Following from this, the study also contributes to inquiries into declining levels of trust in organizations and the subjective experience of violations of trust (Adams et al., 2010; Caldwell and Dixon, 2010; Elangovan and Shapiro, 1998; Gillespie and Dietz, 2009; Keyton and Smith, 2009; Mayer and Davis, 1999; Norman et al., 2010; Schoorman et al., 2007; Six and Skinner, 2010; Tomlinson and Mayer, 2009) by clarifying the unconscious dynamics of such experiences 
and exploring the mediating role that unconscious desire may play in responding to such violations. Finally, the study seeks to contribute a more fine-grained understanding of how and why trust may be “engineered” (Sievers, 2003: 24) in the face of organizational trust violations not only as an unconscious defense (Sievers, 2003) but as part of fulfilling a desire for a stable identity and why, therefore, organizational trust may be more fragile but also more resilient than theorized to date.

The paper proceeds as follows. First, I develop a theoretical framework for conceptualizing the link between trust and identity. Second, the data and methods of interpretation are described followed by an analysis illustrating how trust functions relative to identity work. After a discussion of study findings, the paper concludes by outlining its contributions.

\section{Trust and Identity}

In order to develop a conceptual framework for a more fine-grained understanding of the link between trust and identity, I will first describe how identity is currently conceptualized in the literature and how this might inform its relation to trust. Individual identity work has been described as an ongoing activity of narratively constructing the self (Alvesson, Ashcraft and Thomas, 2008: 15). Specifically, identity work has been explored as a fragile, sociallyconstructed and linguistic construction aimed at producing a coherent identity but frequently fragmented, shifting and insecure with conscious as well as unconscious dynamics (Alvesson, 2010: 203). Most recently there have been attempts to examine the fragility of identity work in view of such unconscious dynamics drawing on the work of French psychoanalyst, Jacques Lacan, to understand not only how this identity work may be experienced subjectively but also how such experiences may be studied as complex linguistic phenomena (Arnaud 2002; Arnaud 
and Vanheule, 2007; Driver, 2005; 2009 a;b; Stavrakakis, 2008). I draw on this perspective here not only because it is crucial for better understanding identity, but because it should explicate the complexities of trust and significantly extend current theorizing on trust in organizations today.

A central idea in Lacanian psychoanalysis is that everything that is real and unique about a subject is not what is articulated but that which is systematically repressed and excluded (Parker, 2005). As such, identity is not that which is most intimate to a subject but is rather what is called an "extimacy" (Parker, 2005: 172). Extimacy refers to an essence or truth of the subject that lies outside of it and can be found not in what is present but rather in what is missing. Therefore, while identity work is about constructing the self in and through language, this self is an extimacy, a misrepresentation and an illusion (Fink, 1995: 7). Lacan referred to this self as alienated (1977b: 236) and a construction in an imaginary order (Lacan, 1988: 177).

The self so constructed is illusory because it is always mediated by language. Language in turn is given to the individual by others. Language is the symbolic order (Lacan, 1977b: 206) formed by social conventions; and it is fundamentally other to the self and represents what Lacan called the Other (1977b: 206). Therefore, when individuals attempt to articulate who they are and what they want, they can only do so by using signifiers that are not of their own making and do not represent what is real for them. The real is missing from the symbolic and subjects are barred from this, as Lacan calls it, order of the real (1988: 219).

The real in turn is that what individuals unconsciously desire but which always eludes them. Whatever is consciously articulated as identity or desire is instead an imaginary attempt at obtaining this. Simply put, it is the fantasy that what is missing can be obtained and that individuals can feel whole and fulfilled. The problem is that imaginary constructions invariably fail. From every narrative construction there is always something missing. Signifiers, or symbols, 
slide around in their signifying chains (Hoedemakers and Keegan, 2010: 1027), our assemblies of symbols, and they never seem to express just exactly what is wanted. That is, we try to fix the meaning of words by attaching them to other words but meaning remains ambivalent and open to interpretation by others. Our words seek to circumscribe our objects of desire, what Lacan referred to as objet a (1977b: 239), yet they always contain surplus pleasure. They are only placeholders in the symbolic for what is really, unconsciously, desired but never found (Benvenuto and Kennedy, 1986: 176).

Consequently, identity work is about looking for objet a as the "it" that will fulfill desire but when obtaining whatever "it" is also becoming aware that this is not "it" again (Lacan, 1977b: 268). Lacanian psychoanalysis does not offer a cure for this (Lacan, 1977b: 218) but underlines that the failure of conscious imaginary constructions contains something powerful and liberating. The subject will always remain barred from the real but in noticing that something is missing, there is at least “a piece of the real” (Ragland, 1996: 200). At those moments when individuals experience that what they wanted is not "it" again, the real appears as an absence made present (Arnaud, 2002).

It is at those moments also that a kind of energy and enjoyment are experienced, what Lacan termed jouissance (1988: 223), a libidinal feeling not the same as enjoyment (Fink, 2004: 157) but similar to the wholeness individuals felt in the womb where all their needs were met without even having to articulate any desire (Arnaud, 2003). Jouissance is associated with experiencing the power of unconscious desire (Lacan, 1977b: 218) and being liberated at least momentarily from the alienation of the imaginary (Lacan, 1977b: 216). It is the energy that comes from being driven by an overwhelming desire that is impossible to know but refuses to be subdued (Lacan, 1988: 210). 
In short, what might provide a more fine-grained understanding of how identity work functions in relation to trust is that at the heart of the subject is a negative ontology (Stavrakakis, 2008: 1041). Trying to understand subjectivity must therefore involve attempting to understand that which is missing and all that is excluded from conscious articulations. But it is also about trying to crystallize what is unique to each subject. While no identity work allows access to the real self or real desire, it nonetheless provides glimpses of how each subject struggles in a unique and creative fashion with what is eluding it. So while each subject is constructed through a generic symbolic order, how the symbolic is used gives us clues to its particulars. As such a Lacanian perspective may inform our understanding of how identity is constructed in and through discourse (Sveningsson and Alvesson, 2003), by observing that a discourse, such as trust, is drawn on that is generic to all subjects but that each subject takes a different and unique position to this discourse (Morrison and Macleod, 2013).

Consequently, we can look at a particular communication about trust and examine the patterns of signifiers and how the narrator may seek to hold them in a particular place, using what Lacan referred to as a "point de capiton" or an upholstery button (Hoedemakers and Keegan, 2010: 1027) by which we try to keep signifiers, like self or trust, from sliding around. This will not allow us to determine who the speaker really is or what they really want. But it provides insights into how they position themselves with regard to a certain discourse. In this way we gain insight into how individuals circle their extimacy in a unique and creative fashion (Fink, 2004: 62) and how this fuels identity work as infinite and never-ending self-constructions (Sermijn, Devlieger and Loots, 2008: 643).

Therefore, a Lacanian framework seems well suited to exploring trust in the context of identity work because it allows us to build on but also extend the recent focus in the field on 
studying trust as a linguistic phenomenon (Li, 2011:16) for which processes of identification are crucial and these, in turn, are also linguistic accomplishments (Maguire and Phillips, 2008). A Lacanian framework contains just such a focus on language and allows us to better understand the complexities of discourses and narratives as that through which individuals articulate who they are and what they want. Further, it offers the opportunity to understand such processes not just as a conscious but also an unconscious dynamic thereby adding another lens through which to better understand trust.

Finally, this framework is well suited to examine trust and processes of identification as socially constructed (Li, 2011; Maguire and Phillips, 2008) because it does not reduce the social to the psychological. In fact, a conceptual understanding of the link between trust and identity informed by a Lacanian perspective, among others, underlines the socially constructed nature of both trust and identity as it points to language as the only means through which people can articulate who they are and obtain what they want (Lacan, 1977b: 206). Language in turn consists of social conventions and imposes otherness and alienation on individuals (Lacan, 1977b: 236). As such, when individuals speak about trust in relation to themselves, language imposes on them the wishes of internalized others (Parker, 2005: 172) to such a degree that even the notion of having an individual self is somewhat illusory (Fink, 1995: 7), which in turn unsettles trust as a signifier. By drawing on this framework, the present study explores how trust discourse serves as a resource for the narrative construction of identity and thereby adds a new vista on trust as a fragile and fleeting accomplishment in an ongoing struggle with identity.

\section{Empirical Material and Interpretation}

Following the call for more "qualitative work" (Maguire and Phillips, 2008: 380) on trust, why people trust, the cyclical nature of trust (Dietz, 2011: 215) and especially the 
experience of the loss of trust (Gillespie and Dietz, 2009), the present study analyzes data on the subjective experience of trust violations. Trust violations were also chosen because they bring the dynamic under study into sharper relief. Much like events that throw identity into crisis are studied to better understand identity work in organizations (Sveningsson and Alvesson, 2003), violations of trust might elucidate how trust functions. Therefore, it is important to keep in mind that the theorized dynamics of trust I am exploring in this data should function the same whether trust is violated or not. I return to this point in the next section.

Following methodology employed in recent trust research (Maguire and Phillips, 2008), individuals were asked to write a story about an experience during which they felt trust in their employer was violated. Stories have been described as a way through which individuals “constitute themselves as subjects” (Gabriel, 1995: 481). Consequently, they have been used extensively for studying identity particularly in relation to trust, as the stories told or written about oneself (Maguire and Phillips, 2008: 378) and a discursive phenomenon explored by collecting and analyzing narratives (Maguire and Phillips, 2008; Maguire, Phillips, and Hardy, 2001). Especially in view of exploring unconscious dynamics of identity, stories have been found to be useful (Gabriel, 1991; Gabriel, et al., 1999: 270). It has been suggested that in "writing we give birth to our selves” (Sermijn et al., 2008: 646) and written stories have been analyzed to better understand unconscious motives and subjective meaning (Gabriel, 1997).

Using purposeful sampling (Glaser, 1978), I approached potential participants likely to have current or prior work experience and who wished to volunteer and share a story with me about an experience with trust violations. In line with storytelling methodology (Gabriel, 1998; 2000), I provided only broad instructions to storytellers hoping to elicit stories of whatever they wished to share with me as “fellow traveler" (Gabriel, 1995: 481) i.e. eliciting stories for 
subjective meaning making (Gabriel, 1991: 871) without judging or signaling interest in factual details. Specifically, I asked them to share a story with me about an event at a current or former workplace in which they felt their trust in their employer was violated. I asked them to write about the events leading up to this experience and to describe how they felt and what the events meant to them. A total of 111 stories were submitted in writing as email attachments for 30 lines per participant on average or 3283 lines of text. To protect the anonymity of respondents all identifying information has been removed from the stories. 66 respondents are male, 45 respondents are female. Organizations to which the stories refer cover a wide range of industries from hospitality, retail and construction to tourism, marketing, public service, transportation, higher education, recreation, landscaping, healthcare, manufacturing, automotive, banking, technology, public administration, energy, agriculture, media, not-for-profits, and real estate. The stories were analyzed using narrative inquiry, a broad qualitative inquiry method suited especially to identity research (Ollerenshaw and Creswell, 2002; Polkinghorne, 2007; Sermijn et al., 2008; Rogan and De Kock, 2005) and narrative discursive analysis in particular (Morison and Macleod, 2013) to first identify common themes and wider discourses in the stories and then also to make space for subjects (Wolgemuth and Donohue, 2006) by examining how subjects position themselves relative to such themes and discourses (Morrison and Macleod, 2013). Therefore, I examined the stories first with regard to how narrators drew on the discourse of trust. I coded the stories as to whether trust in general and trust in the employer specifically were mentioned and how the term was used and explained.

Subsequently, each story was analyzed as a unique expression of ongoing identity work. The stories were coded for identity terms and cues such as when narrators described how they felt about themselves, their emotions and what this meant to them as a person. For example, I 
coded for phrases like "this made me feel less valued" or "trust is important to me because it makes me feel more secure”, or "losing trust made me feel worthless”. After coding the stories for identity themes, I then sought to engage with each as a fragile and illusive construction of identity with multiple entry points and potential fragmentation (Sermijn et al., 2008). In keeping with prior Lacanian organizational research (Bicknell and Liefooghe, 2010; Harding, 2007; Hoedemakers and Keegan, 2010; Vanheule, Lievrouw and Verhaeghe, 2003), and guidelines developed for Lacanian discourse analysis (Parker, 2005), I sought to engage with each story from within the text (Parker, 2010: 166) seeking to highlight how each narrator drew on trust discourse to construct a unique conscious imaginary self (Lacan, 1977b: 236). I looked for how each narrator creatively attempted to fix meaning and to keep signifiers from sliding around (Hoedemakers and Keegan, 2010: 1027). Then I analyzed how each narrator also failed in doing so as I looked for gaps and fissures (Driver, 2013: 416) searching for underlying tensions and what may have been excluded (Bicknell and Liefooghe, 2010).

Moreover, I attempted to find instances when narrators drew on the discourse of trust in an effort "to present a particular self-identity" (Hoedemakers and Keegan, 2010: 1024) but also instances that highlight the fleeting nature of such attempts as struggles with language (Hoedemakers and Keegan, 2010: 1028) and the truth of each subject (Parker, 2010: 167). That is, I do not aim to provide an understanding of what "really" happens inside each storyteller but rather to point to what is fascinating about how each subject organizes particular signifiers (Parker, 2005: 167). In short, my aim here is to make space for the subject in academic work, informed by an ethical position on research investigating subjectivity as a necessarily “incomplete, contingent and corrigible activity” (Parker, 2005: 176). 
While I hope this method illuminates the link between trust and identity, there are also several limitations to this approach. First, it should be noted that the Lacanian ideas I draw on here originate in a clinical context intended to help individuals and bring out the unique subjectivity in single case applications (Parker, 2005: 168) and therefore require translation to organizational contexts (Parker, 2005: 171). Second, Lacanian ideas are intentionally left open to interpretation (Fink, 2004: 65) and a text, as seen from this perspective, does not have a finite and determinate meaning (Parker, 2005: 168). In some ways a Lacanian narrative analysis makes it impossible to claim any particular truth as it is intended to avoid objectifying subjectivity (Parker, 2010: 165) by reducing, boiling down or summarizing a narrative or its meaning (Parker, 2005: 176).

As Lacan suggested, there is no metalanguage (Parker, 2005: 174) or any language that is not part of the struggles with subjectivity that gives rise to it. Hence all one can do is to engage with a text from within (Parker, 2010: 166) and recognize that any interpretation is itself an imaginary project (Parker, 2010: 175) in which signifiers continue to slide around (Parker, 2010: 170). Moreover, data interpretation and the writing of publishable research are always also subject to such limitations (Parker, 2010: 168). Researchers like respondents are confined to struggling together in their attempts to fix meanings and identities as well as the impossibility of ever doing so (Driver, 2007; Harding, 2007). In short, the interpretations I present here cannot serve as generalizable truths. Instead, they should be understood as a "creative endeavor" (Ybema et al., 2009: 316) and an interesting argument in an ongoing debate (Alvesson and Skoldberg, 2000: 276) on the complexities of trust in organizations (Dietz, 2011) while listening with humility and trusting narrators "that meaning will be made" (Hendry, 2007: 494). 


\section{Stories of Trust Violations}

I begin by illustrating how trust is drawn on in the narratives as a discourse that crisscrosses the narrational landscape (Jokinen, 2004: 354) and then explore how each subject positions itself toward this discourse in each story as a complex, fluid and malleable identity narrative (Wolgemuth and Donohue, 2006: 1026). The following is an excerpt from a story written by a public service employee who describes losing trust in her institution after the autonomy given to her by her previous manager is taken away:

Before my new boss was hired, there was a strong sense of trust between my employer and me. I was left mostly to my own devices to complete the job on time and correctly, and my previous boss had confidence in me to do so. This trust made me feel like I was an integral part of the organization and that I was important. Usually untrustworthy people are not given such significant responsibilities, and it made me feel validated... When my new boss was hired, that mutual trust was broken and I was treated very differently. I felt let down and as if my every move was being watched with scrutiny. I began to feel self-conscious about my work and was distracted from performing my best on the job due to this failed trust. I also felt angry that the department had hired such a person and was now unconcerned with her poor managerial skills.

Keeping in mind that narrative interpretation is always a co-creation and that my aim is to respect self-stories as fragmented, temporary and ever-changing (Sermijn et al., 2008: 635), one entry-point into this narrative is to examine how trust discourse is drawn on (Sermijn et al., 2008: 646) in an attempt to fix the personal meaning (Rogan and De Kock, 2005: 644) of trust for the narrator by offering definitions of trust, which are also designed to hold the signifier of trust in place by connecting it to a signifying chain (Hoedemakers and Keegan, 2010: 1027). The narrator seems to define trust in relation to the amount of responsibility and autonomy she is given. By drawing on the discourse of what we might refer to as the cyclical nature of trust (Li, 2011; Rousseau et al., 1998), she narrates how trust was first gained and then lost. 
What seems to anchor down her signifying chain similar to what Lacan called a "point de capiton” or upholstery button (Parker, 2005: 169), is how trust affects her identity. Trust as a shared signifier in the stories, for which this is a representative case, seems to be a discursive resource for identity work in that, what seems to give meaning to her story about trust is how it alternately validates and undermines who she is and how she feels about herself. She describes how trust makes her feel as "an integral part of the organization”. She also describes feeling important and validated through trust and when trust is lost feeling angry, let down, distracted and self-conscious.

Consequently, this story illustrates how the narrators struggle to fix and make meaning (Hendry, 2007: 494) with regard to trust and identity. As she recounts how she felt before and after she gained and then lost trust, what comes into view is that this identity is not only fragile but that something is missing that eludes signification. Trust here may serve as a placeholder for the desire to fill in what is missing from her fragile self. Trust perhaps is the objet a, the object of the desire to secure the self. That is, if only she had trust, then her self would not be thrown into question. But of course her self is always thrown into question anyway. What seems to be repressed is that, whether trust is present or absent, i.e. whether we observe a violation of trust or its routine operation, the self constructed in this narrative cannot be sufficiently whole and feel sufficiently fulfilled. Trust discourse only furnishes an opportunity to experience the extimacy of identity and the fragility of the self and its ongoing struggles with desire.

Additionally, the socially constructed, collective and interpersonal dimension of trust surfaces in how the narrator relates to the persons who established and violated her trust, namely her managers. But importantly, it surfaces in that the other who seems to be addressed in this narrative is a generalized other, the Other as conceptualized by Lacan, whom individuals address 
as they construct the self through language (Parker, 2005: 173). This Other may be referenced when she states that "usually untrustworthy people are not given such responsibility" without explaining who in particular is referred to. Importantly, by answering this call of the Other (Parker, 2005: 173) she validates her identity. But it is also the Other that fails her. The trust signifier here again is the placeholder for the desire to overcome this otherness and get to what is real. Yet, it is precisely the real from which she is barred. So it is not trust that fails her but the absence of the real.

Consequently, trust discourse serves a dual purpose. It is a resource to construct and validate the imaginary self. But it is also trust discourse that is drawn on to unsettle this self as unconscious desire surfaces disrupting the identity of, for example, the responsible and trustworthy employee. As she becomes, as she says, self-conscious and distracted, she also has the opportunity to experience that this imaginary self is not who she really is nor can obtain what she really wants. This, in turn, brings her closer to experiencing something real and become empowered by unconscious desire to be free from the imaginary to continue the struggle and desire something else.

Trust's dual function with regard to identity is also illustrated well in the next excerpt from a storyteller who recounts losing her trust due to unfair treatment, a common cause for the loss of trust identified previously (Maguire and Phillips, 2008). The narrator describes how she was fired without due process:

In the three years I had been with [name of employer] I had never, not once, gotten written up for anything. Not only did I not have any write-ups, no one was there from HR when he [her manager] took me into the office and fired me...There was nothing I could do... I felt like they stabbed me in the back and that they were total hypocrites. I feel like they fudge their own policies when they want to and have no problem getting rid of dedicated employees that have committed many years to them like it's no big deal...I think it's extremely important to work for an employer you trust. It gives people more security and makes them feel more committed to that employer. I personally don't want 
to work for an employer who always has me on edge, nervous about my job security, about them not following through with the things they have promised, or constantly bending and changing the rules when it's convenient for them. When trust is lacking you tend to stop caring. It's hard when things aren't consistent and you're constantly unsure of what will happen. It definitely can make you feel less valued or good as a person when trust is lacking. It makes you feel like you are committing and dedicating yourself to a company that really couldn't care less about you- like you are a replaceable nobody. You lose confidence, motivation, and wonder why you are working so hard for someone that doesn't seem to find trust a priority when you do. It makes you feel like the employer you are working for, spending more time with than your own family, doesn't care about you or your feelings, and that can really hurt. It can definitely bring down your self-esteem and make you feel worthless.

This story illustrates again how the narrator tries to fix the meaning of trust in a signifying chain around fair treatment, job security, being loyal to dedicated employees and caring about employees' feelings. As the narrator draws on the discourse of the cyclical nature of trust (Rousseau et al., 1998) and describes how her trust was violated, the story illustrates well how trust discourse is also drawn on to engage in identity work. Specifically, we can see how through trust an imaginary self is constructed, here the dedicated and committed employee who wishes to feel secure and cared for. We can also see how this construction is disrupted as the trust signifier slides around between the things that were done to her and how this makes her feel as an uncared for and replaceable nobody.

But of course her identity is also repaired by pointing to trust as the problem, which can be solved by having an employer, for example, who makes trust a priority, cares for her feelings and values her for working hard and spending more time with than her family. That is, trust is both validating her self, but it is also what undermines this self. The trust signifier slides around in the signifying chain as that which is desired but impossible to attain, namely to define the self and fulfill its wishes. All this narrator is left with is to wonder what the Other wants (Parker, 2005: 173), why her employer is so uncaring or arbitrary, for example, and continue the search. 
The next excerpt is taken from a story that illustrates well how elusive but also how, in

some respects, resilient trust may be in the context of identity work. The narrator in this story

describes losing trust in his employer and quitting after he discovers that the owner of the

company cannot be relied on:

To lose trust, it first has to be gained. I absolutely trusted my boss from day one... Just after I was hired, my new boss told me that instead of doing a retirement plan, like a $401 \mathrm{~K}$, he gave us employees a percentage of a share in the company for hours worked. Other things that companies use to build trust were also promised (such as health insurance). In giving us shares in the company, he made me feel like I had a more vested interest in how the company did. I felt like this was a place that I could work at for a long time. This was going to be my career. I loved the job security...I had paid vacation and paid days off. Having all this...made me feel like a valuable employee and I wanted to bring my best to the table every day. Trust started to build right off the bat.

Unfortunately, I started to learn more about the company and got to know the boss better and better as the months and years passed by. The trust that had grown between us was a façade. I learned that the boss had a real serious issue with alcohol...Temper tantrums became the norm...It was one of these tantrums that finally broke the straw. The trust that I thought had developed was essentially being broken down the whole time. In my fourth year on the job, a tantrum led to the boss yelling, "I am taking away the fucking shares too!” It is hard to say if I had any trust left in him at that moment or not, but it was most definitely gone then...I left the company about a year after the tantrum. I think it took me so long to leave because I had so much initial trust in the promises that were made. I had wanted to leave well before the shares were taken away, but I deeply believed that this was my career. I think that I have a hard time letting go of something that I put so much effort into. I do not want to compare it to something I think is a more devastating loss, like losing a family member, but it was certainly difficult. I was not sure where to turn to, which prolonged changing my path. I felt like I was in no-man's land. The Clash lyric, "should I stay or should I go" played in my head all the time...Ultimately, I felt that I had to make the choice to leave because I ended up not being able to believe anything that came out of my boss's mouth. The amount of stress that built up affected life outside of work on an unhealthy level. The main thing that I think I learned about myself was that if I had zero trust in my boss, that I could not leave work at work...Simply put, I learned a lot of lessons about trust... When I had these feelings [of trust] at my job I thought that I would do anything that was asked of me, and happily do those tasks. I also had the feelings that the organization would do many things for me as well, such as understanding if I were sick, injured, or had personal issues. During this "honeymoon” period, I never had my eyes open for other opportunities. When these feelings started to fall apart I was constantly looking for new and better employment...If the mutual trust and respect had remained I would still be there. 
This narrative illustrates well how trust discourse is not only drawn on to construct identity but also how complex trust becomes in this context. As the narrator describes the cyclical nature of trust as it was gained and then lost, he also points to its elusiveness. He refers to trust as "a façade" and there is a sense that this façade may be tied to the fragility of the imaginary self that was constructed in what he refers to as the "honeymoon phase" of his employment relationship. However, when trust was broken, the identity he had constructed was thrown into question. To be clear, this identity, from a Lacanian perspective, is of course always thrown into question. We might have observed this even in the absence of trust violations simply by exploring the ambiguities, tensions and other rhetorical constructions that point to the inevitable unsettling of all imaginary constructions (Benvenuto and Kennedy, 1986: 13).

However, the trust violation throws this unsettling into sharp relief and the narrator points to this as he compares his experience to being almost as severe as losing a family member. Importantly he seems unable to give it up. He describes being in a "no-man’s land”, being unable to decide whether to leave or not, experiencing unhealthy levels of stress and not being able to maintain the boundaries of work as something he can leave behind at the end of a work day. As he describes it, the less he trusted his employer, the more work intruded into his life. The identity he had committed to as a "career" employee with "absolute” trust in his employer seemed to fragment yet hard to let go of. Consequently, even as he discovers trust to be a "façade”, and asserts that real trust is required, he nonetheless remains.

In this struggle we can see narrative fissures again and also how trust may operate in the context of identity work. When identity is successfully constructed through trust discourse, the façade of trust may suffice to serve as a resource. As we saw in the story, the narrator did not leave his employer until he learned, as he describes it, lessons about trust, and recognized that 
work was intruding into his life in unhealthy ways. In short, identity work had to be undertaken before the absence of trust resulted in him leaving. It was not merely the experience of losing trust that affected him staying, but, importantly, also how he processed this loss through his identity work. Trust, in this sense, was resilient as long as his imaginary self continued to be validated, perhaps engineered as a façade. But as soon as the imaginary self became unsettled, trust was experienced as being broken. As soon as it was experienced that trust was an impossible object of desire and the "it" the narrator was looking for was not "it" again (Stavrakakis, 2008: 1054), identity was thrown into question, and then the narrator left. In this way identity made trust more resilient but identity work also unsettled trust, as the narrator realized it was only a "façade".

If this can be considered a moment where the narrator became liberated from the imaginary order, it should be noted that this was only temporary. At the end of the narrative, trust is reinstated as an object of desire, an objet a, and his imaginary self is repaired. He returns to seeing himself as an employee who may not be, but could be, happy doing whatever is asked of him if only he had the trust that he thought he had before. As such, trust itself remains the object of desire and the lack of fulfillment he received from trust is not blamed on its impossibility as fulfilling real desire, but rather on the employer who did not deliver, as he states, "absolute" trust. In this way, the structural lack of the trust signifier, which always promises more enjoyment than it can deliver, is quickly covered over again through another imaginary construction. Consequently, while he momentarily experienced the jouissance of coming face to face with structural lack, namely the real, he quickly and inevitably returns to an imaginary self that can find what he is looking for, like trust. 
This important dynamic of how trust functions to both validate and unsettle identity is also well illustrated in the next narrative by a retail store employee whose trust in her employer was broken when her manager repeatedly violated agreements he made with her about her schedule and she discovered discrepancies in her pay, which led her to monitor her pay checks closely:

I hated that fact that I was forced to do this. This was a major reason I lost trust in that manager. My pay is a big deal for me and...I dislike the fact that I had to watch for it, but also if there was a mistake I dislike bringing it up to my manager because it would only upset him more. I think it was ridiculous that I had to do that at all and that a grown man couldn't do his job correctly...For me this was a huge problem and although I was angry to the point of quitting I did learn a very good lesson. At the time I felt that a person should keep their promise...I feel that this was the major issue for me and I still get frustrated over what had happened 5 years ago. This "betrayal” hurt me deeply and is something that I will always keep with me... Overall I do care how people view me and...I feel bad that manager Q doesn't see me as the cooperative employee that I used to be but I wish he could overlook that.... and see my other great qualities. All I know is that I have to be true myself, not let people walk all over me, and just keep doing a good job at things that I am meant to do. If I could change things between myself and manager $\mathrm{Q}$ then I might have, but I can't and I have to live with the experience of what was.

As in previous narratives, the narrator attempts to fix the meaning of trust by connecting it to signifiers such as keeping promises, not having to check up on the employer to receive the correct pay and getting upset when problems are uncovered. Trust is also tied to validating her identity as someone who does not complain or like to make her manager upset and as an employee who as she says is "cooperative", does a "good job" and has "great qualities". But trust is also tied to throwing this identity into question. The narrator feels deeply hurt and betrayed. Moreover, the anger she felt of having been walked all over is an experience, as she describes it, that she will always have to live with.

As she reflects on the consequences of the events, we can see that there are not only moments when her identity is thrown into question but that perhaps her identity work has 
changed permanently. She speaks of having learned "a very good lesson” and of resolving to be true to herself and not letting others walk all over her. Of course this is likely another imaginary construction of the self in that she is now a person who has learned such things and can return to validating that she really is the cooperative and good employee. Moreover, she may not find the trust she initially sought but perhaps a modified form with some disclaimers such that trust might be fixed again in the signifying chain to being true to oneself.

We see how the experience of confronting an absence of trust also allows her to unsettle imaginary constructions of herself and the alienation of the otherness it invariably imposes. She even reflects on this otherness as she describes how she cares about how others see her and how she wishes that her manager could perceive her in a way that validates the imaginary construction of herself as the good employee. That is, we see how she both internalizes but also, at least temporarily, externalizes otherness and perhaps creates new positions toward this otherness. In this way, she draws on trust discourse to circle the structural lack in her identity and to play with different positions toward it. Even as she asserts that she, for example, must remain true to herself, she still desires for her manager to see her differently and reaffirms her desire to "keep doing a good job”. As she points to this fissure in her narrative, she concludes that this is an experience she will have to live with and we may speculate that her imaginary self has been unsettled more permanently. Drawing on trust discourse in the way she has may allow her to be more aware of this unsettlement and therefore, in future, continue to have a greater potential for jouissance.

This potential may also come into view in the next narrative by a resort employee whose trust in her employer was broken when she was reprimanded for following corporate policies on how to handle a guest complaint: 
I was hurt by the whole situation. I felt as if my employer didn't value their employees. They only seemed to care about making money and keeping the guests happy. After the situation I felt betrayed by my employer, and undervalued. I was further insulted the next day when they reminded everyone of the rules. I was taken aback that my employer had the audacity to tell us how to do our jobs correctly the next day, when the day before I did my job correctly and was not supported by my supervisors. When I lose trust in someone it means that I lose confidence in them. They are no longer seen as a reliable person to me. It doesn't necessarily make me feel less valued, because in this situation I know I was right and they were in the wrong. I lost respect for them as employers. To me they were no longer dependable to make the right decision for their employees, just what was best for them. Loosing trust in anyone can leave someone with a sense of betrayal, that they weren't good enough to have a mutual respect and trust. I feel like if I always do the best that I can do, then it reflects more on them, than on me.

We can see here again how the imaginary self is both validated and unsettled through trust. She feels both validated as an employee who knows she is right and does her job correctly and betrayed and "undervalued". As she concludes that this betrayal may make her feel like she is not "good enough" but that the lack of respect and trust reflects more on "them" than on her, we also have a sense of the "margin of freedom" (Stavrakakis, 2008: 1055) that she gains as she positions herself toward this lack. Similar to previous narrators, it appears as if there is not only momentary jouissance from encountering the fissures in her imaginary self-constructions but also an empowerment to continue her struggle in creative ways perhaps allowing for a lighter touch or a lesser attachment to any given imaginary construction and therefore potential jouissance.

The more permanent unsettling of identity work is also illustrated in the next excerpt from a story of a retail employee who was accused of stealing later found innocent:

This event made me feel very frustrated for a long time; eventually I realized that although [her manager] questioned my character I was in no way guilty and decided to let it stop bothering me. It was not my problem but really it was her lack of trust and her insecurity with her business. At the time of being "interrogated" I felt really sad and bitter towards her because of her accusations. I think our trust was damaged forever and although we both got past it I don't think there is a way to forget entirely that at one point she found me untrustworthy. I don't think she handled the situation well at all, instead of 
sitting me down to have an adult conversation she instantly started blaming and pointing fingers. The situation in whole made me a stronger person and made me consider how I might handle a situation like that different.

We can see here not just the cyclical nature of organizational trust but the concomitant cyclical identity work this seems to prompt. We can see the narrator move from feeling validated as an innocent person and presumably a trusted employee to feeling sad and bitter about being thought of as the opposite and then returning to the initial self-construction as the innocent and trustworthy employee. Yet not quite. As she reflects on the fissures in her identity work, she also underlines that she thinks her manager did not handle the situation well, and that it cannot be forgotten entirely how her manager thought of her in this situation. Therefore, we can interpret her statement that she is now "a stronger person" as meaning, perhaps at an unconscious level, that the imaginary has become more permanently unsettled so that now there must be more effort expanded to re-create the imaginary and that fissures may remain closer to the surface.

Such complexities are also visible in the following excerpt in which the narrator describes working for a healthcare company and one day, without warning, having the HR manager ask her to sign non-compete and confidentiality agreements as a matter of routine, then, on the same day, being fired by the new CEO after helping him come up to speed on all the work that she had done:

I was upset about it but I knew I didn't want to continue to work for a company that would do this to someone. It stung, I felt betrayed and certainly under appreciated. I doubt they even knew about all the extra little things I did because they never took the time to ask me about my job, or to evaluate my performance. I received a note after from my direct supervisor the day after. He apologized and said he had no idea that it was going to happen and how much he would miss me and all I have done. He said he knew no one but him would understand all the extra things I did for the company. That's all I needed. I don't know if they miss me or not, but I am on to bigger and better things, and hopefully with a gained knowledge of the importance of working for a company that treats its employees as an asset. 
As we have seen in prior stories, the trust violation prompted an unsettling of the imaginary self as she describes feeling betrayed and underappreciated. Yet, surprisingly enough what she hangs on to is not that she was fired without warning or cause but that she was never appreciated for her work and dedication. As she receives an apology from her supervisor, her imaginary self, as the dedicated employee, seems repaired, even revitalized, and she underlines that she is "on to bigger and better things”. In this sense while the trust violation prompted a fissure in the imaginary self construction, it also strengthens this self by providing reasons for why she really is this employee who was just working for the wrong company. Importantly, there is then hope of fulfilling her desire to have this self validated even more firmly by a future employer who treats employees better and will offer her the trust she is looking for.

This also provides the narrative resources to cover up any gaps that are thereby exposed therefore strengthening the imaginary further, which seems well illustrated in the next story. In it an employee of a car dealership working on collision repairs recounts how over the course of several years he lost trust in his employer and finally left after his immediate supervisor continued to slander his reputation and led the owners of the dealership to give him less and less work. He describes his ordeal in great detail and how much of the pain did not actually occur until after he left:

I felt betrayed and alone. I felt like I wanted to smash something or somebody, but couldn't. I was physically and financially broke, and for the first time I felt mentally and emotionally broken. I did not have the money to sue, I didn't even have the money to buy the gas I needed to put in the borrowed car I had to drive across town to confront this ass clown in person [his former supervisor]. I felt so hopeless and wondered where I took a wrong turn knowing it was when I decided to get a job [with this employer]. I have beat myself up over it time and time again. I have great anxiety still when I think about applying for a position in the future due to the fact that I wonder if what is said will be the truth. I feel like someone else has control over me and my future. I don't really get mad, I just get over. Not over it, just over...Not in a physical or violent way. I get back by doing better and making more than you. I do this by my actions in letting you know that no matter what, I will do better than you, and let you know it...I've had enough. I'm 
madder than hell about it, and will stay that way until I am where I want to be. Every day I wake up and think about how much I missed my dog, my house, and other things because of the jam I put myself in by staying at [name of employer] when I should have left. It eats at me and this is what keeps me going when I wake up and am racked with pain in my joints and body from years of hard manual labor. Many times driving home in 2007 and 2008 I would drive home and cry thinking how stupid I was to trust these people. I know better than that, I should have not made such a wrong turn, beating myself up till I fell asleep. But you can’t stay that way. There isn't enough time in life...

We can see the fissures in this narrator's identity work as he oscillates between rage, devastation and the resolve to come out a stronger and better person whose success will be the envy of the people he felt violated his trust and wronged him in so many ways. As he describes his physical and emotional pain in detail, how much he still worries over what happened and how he feels he cannot trust even future employers, we see how he is eaten up with anxiety and self-doubt as well as with the desire to exact revenge, "get over”, and move on with his life. We can see the anger that seems to stay with him as a validation of his imaginary self as a strong and successful person, as well as how this self is undermined continuously as the violence he wishes to exact on the Other is literally turned inwards as he describes beating himself up.

The tension of his identity work and the sense of a permanently unstable construction that has many fissures is visceral in this narrative. Moreover, the alienation that comes from imaginary constructions is also palpable. The narrator describes how he cannot understand or forgive himself for staying as long as he did putting up with an employer he did not trust. As in a previous narrative we can see that there seems to be a lag effect in that trust may be lost but not lead to leaving the employer until his identity becomes sufficiently unsettled. It is telling here that the narrator comments on how much the loss of trust hurt him even years after the event actually took place and how he describes feeling as if someone else is running his life. He cannot understand why he worked for this employer in the first place or why he did not leave much sooner. Indeed, we have the sense that his imaginary self-constructions are continuing to rupture 
even as he denies this. He speaks of rage and of being madder than hell and then denies being mad, saying that he does not get mad but get over. We see him proclaiming that life is too short to continue to be devastated and yet he seems far from "over" it as he cares very much that the people who wronged him know how successful he has become.

We see how identity work here makes trust resilient in that this narrator apparently did not act on the loss of trust until his imaginary self-construction was severely disrupted. As this narrator continues to process who he is and what he wants, years after his trust in his organization was violated, we get a glimpse of just how complex the interaction between trust and identity can become. Remarkably, even if trust in a particular employer is lost, the desire to regain trust and the belief that this is possible are concomitant with the continued desire to regain the imaginary identity thereby threatened.

Consequently, we might interpret the engineering of trust as a defense against the absence of trust (Sievers, 2003) as well as an act of overcoming the structural lack that marks the conscious self. We see this dynamic in the final story excerpt I analyze here by a narrator who describes in great detail how she worked for an employer in the hospitality industry even after her trust was broken. She describes how right from the beginning of her employment relationship agreements were not kept about what her job responsibilities and work hours were and how she was bullied and verbally and physically harassed and still remained even to her own surprise:

I have always told myself, what doesn't kill me will only make me stronger...but where is it that you draw the line between physically dying/ being gone forever, and dying internally, from emotions tearing you apart from the inside out? I guess one will never really know... What I do know is that I was dying internally. I over worked myself. And I love to work, don't get me wrong, but when I am working with people who disrespect me and people which I lost trust with from day one, I don't love it at all. In fact I strongly dislike it...I felt angry at myself for not standing up for myself more, but I felt even angrier at people for even treating me like that to begin with. I cried every night ....after being screamed at for hours and hours at work daily and nightly because nothing I did was ever good enough and I never received any type of positive feedback, so I just 
worked harder...thinking positive feedback would come eventually... And all of this wasn't enough to make me leave?' Trust was long gone...but I continued to work...At the time I started to realize... as I thought to myself all day everyday 'I feel so sick that I can't even eat, I have no appetite, I am pale, and my energy is at an ultimate low...I feel so upset and hurt and angry, most of all degraded. I feel like I am actually worth nothing and I am still trying to prove to these people that I am worth something. I have been torn mentally, physically and emotionally from the inside out...But it always came back to my extremely driven personality reminding me of my one underlying promise I have always had to myself: Always finish what I have started, and to never give up. Even on the hardest days when I wanted to give up, I didn't let myself because what doesn't kill me will only make me stronger. At the time I was starting to realize though that this job wasn't making me stronger...it burned my heart and soul to death and it literally killed me inside...but if I knew what they were saying wasn't true why was I so upset?...I felt ugly, miserable and unstable... Though this job didn't necessarily make me stronger, it did make me realize what I never want in a work place ever again, and also how to deal with difficult people. Because looking back on that experience gives me the chills and I know that I will never in my life allow anyone, I don't care who they are, to treat me with such great amount of disrespect ever again. This job also helped me realize the reality of trust lost in a job setting, I tried time and time again to convince myself that I could trust what these people were telling me...but wait wasn’t trust was lost from the start?...But honestly, once you lose trust in someone, even if you think you have trust in them again... and before they broke your trust, you never spent a single minute worrying or wondering about the issues you are worried about now. All because trust was lost and it's not coming back.

In this narrative the complexities of trust in the context of identity work are thrown into sharp relief. We see the narrator using trust discourse to validate her imaginary self as a hardworking and dedicated employee who finishes what she starts and believes in herself enough not to trust an untrustworthy employer. Yet we also notice that her belief in her ability to trust her employer and her need to work hard to regain trust persisted. Only when this self seemed to “die”, did she regain the strength to leave her employer and still, to this day, she wonders why she tried so hard to make something happen that seemed impossible. As her narrative weaves in and out of the fissures of her unsettled imaginary identity work, we can see just how much the trust discourse is sucked into the vortex of structural lack. It seems to begin slowly and then takes on momentum as she describes in greater detail just how much she felt wronged and threatened by her untrustworthy employer. Her desire to reassert who she believes herself to be seems at first 
fueled by the vanishing organizational trust and only after she recognizes this, does she change her situation.

Trust here furnishes the resource not to encounter her structural lack but rather to circle it creatively. As she switches positions from the hardworking employee who will persevere to the person made stronger through learning her lesson and coming to terms with the loss of organizational trust, she circles the missing real, namely that she is not who she says she is, nor unconsciously wants what she consciously pursues. Even as we sense the empowerment and jouissance that she may experience as she realizes the identity she had initially constructed was failing, we also see the power of unconscious desire pushing her onward into more imaginary constructions. As she proclaims that it was all due to the loss of trust, we may notice how trust and a stable identity remain for her both possible and desirable. It is not that trust and identity are marked by an inevitable lack but that they were merely temporarily misplaced or absent and can be recovered as she resolves to never be treated in this fashion again and now sees the "reality of trust lost in a job” presumably to find it again with another, more trustworthy, employer.

\section{Discussion}

From the foregoing analysis, we can see how trust discourse is drawn on as a generic discourse with shared themes (Rogan and De Kock, 2005: 643) across the stories' narrational landscape (Jokinen, 2004: 354). The narrators stress how important they find trust to be in employment relationships as a fundamental assumption that the employer will operate in a trustworthy manner (Gillespie and Dietz, 2009: 127). The stories also underline how painful and devastating violations of trust can be providing a glimpse into the subjective experience of such violations as, on the one hand, necessarily elusive linguistic constructions, but, on the other, associated with pain real enough to the narrators. The analysis also illustrates how each narrator 
takes a different and unique subject position with regard to such wider discourses of organizational trust. As we saw, each narrator sought to fix the meaning of trust by defining it subjectively, as, for example, relating to autonomy, or consistency and care, or the fulfilment of promises or predictability. Importantly, each narrator drew on trust discourse to undertake his or her own identity work. That is, trust discourse served each to construct an imaginary self that can be defined and fulfill its desires. Whether it is to be the good employee or the valued person, each narrator drew on trust discourse as a resource to define who they are and what they want.

Trust discourse also served the narrators to experience the disruption of this imaginary self. Each narrator came face to face with this imaginary self being thrown into question as they lost the organizational trust they thought they had. So each narrator had an opportunity to reflect on him or herself as feeling devalued and to look behind, what another narrator described, as the façade of trust, and not finding what they were looking for. As such, trust discourse also served as a resource to experience liberation from the imaginary and, at least momentarily, obtain a piece of the real (Ragland, 1996) as the experience that the "it", or trust, they thought they had found was not "it" again.

Of course the imaginary invariably returns. As the narrators explain the causes of trust violations and reiterate how important they continue to find trust, they also repair the imaginary self by reinstating trust as a placeholder for the desire to be whole and fulfilled. That is, as they identify causes for why they did not find the trust they thought they had with an employer, they also validate again that they are who they say they are and can find what they are looking for. For instance, they are responsible and high performing or valued employees that can find trust in their employment relationship. They just have to find a more trustworthy employer. 
The key point here is that trust seems to serve a complex function in the context of identity work and exhibits similar qualities to identity with regard to being a fragile and temporary accomplishment aimed at stability but often under construction (Alvesson, 2010: 203). This does not mean that the fragility of trust that is highlighted here is an indicator of trust being merely the illusory product of the naivety of the narrators. As we saw in the stories the narrators were capable of defining and judging trust for themselves and also to behave accordingly by, for example, leaving. Rather, the analysis presented highlights that trust, like identity, always has an illusory quality serving as a placeholder for the unattainable real, and that it has this quality whether trust is violated or not.

Consequently, trust may not only consist of attempts to assess the trustworthiness of an other (Rousseau et al., 1998) but also importantly of attempts to respond to the desires of an internalized Other. Therefore, it can be understood in the context of the otherness of the symbolic order through which the meaning of trust and identity are fixed as well as unsettled. This does not mean that trust is not an interpersonal dynamic that involves other people, but merely that identity work is an important part of this dynamic. That is, trust is not independent of others, nor can the social and political be reduced to the psychological and trust seen only as an intra-psychic phenomenon. Instead, the foregoing analysis is designed to elucidate the complexities of trust as a constructivist, linguistic and elusive phenomenon (Li, 2011:16) whose absence and presence may be as much a function of systemic organizational issues (Maguire and Phillips, 2008) as of the struggles with identity.

\section{Conclusion}

Keeping in mind the limitations of the methods and framework as outlined previously, the term conclusion is used here with some caveats. I would like to honor the subjectivity of the 
respondents who shared their stories with me by hesitating to reduce them to objective findings (Parker, 2005). The conclusions described here are not intended to offer generalizable truths but rather as encouraging an ongoing conversation (Barone, 2007: 465). Having described how the conceptualized dynamics may be illustrated through specific cases, I can however outline some of the points this study hopes to contribute to such a conversation. First, the study suggests that Lacanian theorizing contributes a new vista on organizational trust in the context of identity work. It redirects the connection made in prior research that identification between individuals or between individuals and organizations leads to organizational trust (e.g. Maguire and Phillips, 2008) by suggesting that organizational trust may serve a similar function to generalized trust (Groarke, 2002: 561) as a fundamental assumption that characterizes employment relationships (Gillespie and Dietz, 2009: 127) and provides discursive resources for ongoing identity work.

The study also provides additional insight into why people trust (Dietz, 2011: 215) because they draw on trust discourse to validate who they are and obtain what they consciously identify as what they want. Put simply, individuals may trust because it serves their imaginary identities and, as we have seen in the foregoing analysis, feel validated as, for example, responsible and worthy persons. Unconsciously, of course, trust discourse also serves other purposes, namely to experience that the consciously constructed identities are not real and that the conscious wishes articulated are not what is unconsciously desired. Therefore, individuals may also trust because they obtain jouissance from not getting what they want (Lacan, 1988: 241). They may draw on trust discourse to experience a kind of pleasure of encountering the real as an absence made present and empowerment from being momentarily freed of the imaginary. Third, and following from the point made above, the study also offers additional insights into the complexities of trust as a socially constructed, linguistic and elusive phenomenon (Li, 
2011: 16). It advances the idea that identification is never just an interpersonal phenomenon related to the persons involved as the target or source of trust for example, but also always already interpersonal and socially constructed as a linguistic construction. Consequently, the otherness of trust is not just that trust is an expectation about being vulnerable to another (Rousseau et al., 1998) but that trust as a signifier in a symbolic order is always already an otherness. Therefore, while the dynamic I point to here was highlighted by studying trust violations, trust as a discourse, in general, is necessarily implicated in all individual attempts to narrate the self through language and the failure to do so in an authentic and real fashion. Both trust and identity, from this perspective, are part of the same struggle to attain the real and yet remain barred from it.

As a result, the study suggests that trust is not only connected to identity work but that it is timely and relevant to conceptualize and examine trust using approaches similar to what is done in the field of identity work. Since identity is now commonly viewed as a fragile and fleeting accomplishment best researched as an ongoing narrative construction that is plurivocal and co-performed (Sermijn, et al., 2008), trust may also be fruitfully researched in this way. Therefore trust could be explored as an ongoing narrative construction analyzed not only for what is articulated but also for what is missing. Specifically, trust could be explored, from a Lacanian perspective, by accounting for the fragility of sliding signifiers and the many voices that co-perform trust not just as an organizational accomplishment (Maguire and Phillips, 2008) but as mutual struggles with organizational identity (Driver,2009a), in particular, and individual identity work (Driver, 2009b), in general.

This in turn provides additional insights into the cyclical nature of trust (Rousseau et al., 1998). The waxing and waning of trust may be as much a function of previously identified 
factors (Maguire and Phillips, 2008), as of struggles with identity and unconscious desire. If the self that is consciously constructed in and through trust discourse is not, and cannot be, what is unconsciously desired, then, as unconscious desire disrupts such constructions, trust discourse is also unsettled. Put simply, the disruptions of the imaginary and the sliding of the trust signifier may also be amplified in the discourse of organizational trust and thereby widen the subjective spaces in organizations (Gabriel, 1995) in which individuals are free to be subjects of the unconscious (Arnaud and Vanheule, 2007). Stories like the ones collected for this study do not only further solidify trust discourse as reiterating how beneficial and desirable organizational trust may be. They also provide a space in which individuals can engage in self-reflection and question what they think trust is or means to them. As one narrator describes it "this taught me to let go" and another describes "Every time I remember this I die a little bit on the inside." From the perspective developed here, what may be let go of or dies may be the imaginary self that knows who it is and what it wants. As such, stories like these make space in trust discourse for the unsettling of the imaginary and the otherness and extimacy that marks the experience of work, self and organization (Arnaud and Vanheule, 2007).

Fifth, the study provides a more fine-grained, qualitative analysis of the subjective experience of violations of trust (Gillespie and Dietz, 2009). By exploring how individuals narrate trust violations, the study offers a glimpse of how individuals process such experiences not only by reiterating the wider discourse of trust but also by taking unique positions toward it. Therefore, the study offers the insight that the subjective experience of trust and its violations in organizations may be better understood by analyzing narratives in depth. In particular, it suggests taking a close look at how individuals struggle to fix the meaning of trust and how the trust 
signifier slides around in signifying chains illuminating how individuals creatively engage with trust and in doing so are born anew in each story (Sermijn et al., 2008: 638).

Finally, the perspective advanced here provides further insights into why individuals may "engineer" trust or communicate about its virtues despite the absence of the experience of trust in many institutions today (Sievers, 2003: 24). If trust can be understood as functioning at the site of identity then trust discourse may be continuously in demand as a resource for both identity validation and the unsettling of conscious self-constructions. Consequently, trust discourse may be engineered not merely as a defense against the experience of its absence (Sievers, 2003) but also by way of appropriating such resources for identity work. As such, trust discourse may not only serve as a "poisoned chalice” (Skinner et al., 2014) and resource for subjectification (Johnson and Gudmand-Hoyer, 2010: 337) and employee control (Grey and Garsten, 2001), but also a space where individuals are energized to obtain "a sense of self” (Lacan, 1988: 223).

This notion, in turn, might be a fruitful way forward for exploring what have been identified as declining levels of organizational trust and a growing interest in trust violations (Caldwell and Dixon, 2010; Gillespie and Dietz, 2009; Keyton and Smith, 2009; Mayer and Davis, 1999; Schoorman et al., 2007). If trust discourse is not only engineered but appropriated in the context of ongoing identity work, then more research like the present study could be undertaken to examine what role not only the presence of trust but also its absence may serve for individuals and organizations. As I have sought to illustrate in the stories analyzed for this study, individuals want trust to feel validated and describe working very hard to please an internalized Other. Similar to not ever being “employable enough” (Cremin, 2009), individuals may feel as if they can never find an institution that is trusting enough, that they are being trustworthy enough or that they can have "absolute" trust. In this way, trust, like employability, may serve a 
productive role for organizations as furnishing impossible but seductive objects of desire that employees may work very hard to obtain (Cremin, 2009).

However, as individuals also experience that something is always missing from organizational trust or that this trust is violated or absent, trust discourse also serves a productive role for individuals as a liberating and empowering struggle with failed imaginary constructions. Put simply, the inevitable failure of trust to deliver the real also gives individuals a unique opportunity to have at least a piece of it (Ragland, 1996). Therefore, a decline or absence of trust may serve a productive role for individual identity work that may be similar to the productive role played by the lack that often surfaces in leadership as an empowering struggle with a contested identity attractive to both leaders and followers (Driver, 2013). Like leadership, trust may be attractive not despite but because of what is missing from it as an emancipatory space (Stavrakakis, 2008) in which subjects can find different ways to relate to each other and the organizational stressors they may experience (Vanheule et al., 2003). Put simply, individuals may find new ways to relate to issues around organizational trust as they have an opportunity to experience that the trust they had, or wished for, was lost and, importantly, may not have been what they desired in the first place.

\section{References}

Adams, M. 2004.Whatever will be, will be: Trust, fate and the reflexive self. Culture \& Psychology, 10(4): 387-408.

Adams, J.E., Highhouse, S., and Zickar, M.J. 2010. Understanding general distrust of corporations. Corporate Reputation Review, 13(1): 38-51.

Alvesson, M. 2010. Self-doubters, strugglers, storytellers, surfers and others: Images of selfidentities in organization studies. Human Relations, 63(2): 193-217.

Alvesson, M., Ashcraft, K.L., and Thomas, R. 2008. Identity matters: Reflections on the construction of identity scholarship in organization studies. Organization, 15(1): 5-28. 
Alvesson, M., and Skoldberg, K. 2000. Reflexive Methodology. London: Sage.

Arnaud, G. 2002. The organization and the symbolic: Organizational dynamics viewed from a Lacanian perspective. Human Relations, 55(6), 691-716.

Arnaud, G. 2003. A coach or a couch? A Lacanian perspective on executive coaching and consulting. Human Relations, 56(3): 1131-1143.

Arnaud, G. and Vanheule, S. 2007. The division of the subject and the organization: A Lacanian approach to subjectivity at work. Journal of Organizational Change Management, 20(3): 359369.

Barone, T. 2007. A return to the gold standard? Questioning the future of narrative construction as educational research. Qualitative Inquiry, 13(4): 454-470.

Benvenuto, B. and Kennedy, R. 1986. The works of Jacques Lacan. New York: St. Martin’s Press.

Bicknell, M. and Liefooghe, A. 2010. Enjoy your stress! Using Lacan to enrich transactional models of stress. Organization, 17(3): 317-330.

Caldwell, C., and Dixon, R.D. 2010. Love, forgiveness, and trust: Critical values of the modern leader. Journal of Business Ethics, 93: 91-101.

Colquitt, J.A., Lepine, J.A., Zapata, C.P., and Wild, E.R. 2011. Trust in typical and highreliability contexts: Building and reacting to trust among firefighters. Academy of Management Journal, 54(5): 999-1015.

Cremin, C. 2009. Never employable enough: The (im)possibility of satisfying the boss's desire. Organization, 17(2): 131-149.

Dietz, G. 2011. Going back to the source: Why do people trust each other? Journal of Trust Research, 1(2): 215-222.

Dirks, K.T., and Ferrin, D.L. 2001. The role of trust in organizational settings. Organization Science, 12(4): 450-467.

Dirks, K.T., and Ferrin, D.L. 2002. Trust in leadership: Meta-analytic findings and implications for research and practice. Journal of Applied Psychology, 87(4): 611-628.

Driver, M. 2005. From empty speech to full speech? Reconceptualizing spirituality in organizations based on a psychoanalytically-grounded understanding of the self. Human Relations, 58(9): 1091-1110.

Driver, M. 2007. Reviewer Feedback as Discourse of the Other: A Psychoanalytic Perspective on the Manuscript Review Process. Journal of Management Inquiry, 16(4): 351-360. 
Driver, M. 2009a. Struggling with Lack: A Lacanian perspective on organizational identity, Organization Studies, 30(1): 55-72.

Driver, M. 2009b. Encountering the arugula leaf: The failure of the imaginary and its implications for research on identity in organizations. Organization, 16(4): 487-504.

Driver, M. 2013. The Lack of Power or the Power of Lack in Leadership as a Discursively Constructed Identity. Organization Studies, 34(3): 407-422.

Elangovan, A.R., and Shapiro, D.L. 1998. Betrayal of trust in organizations. Academy of Management Review, 23(3): 547-566.

Fink, B. 1995. The Lacanian subject. Princeton, NJ: Princeton University Press.

Fink, B. 2004. Lacan to the letter. Minneapolis, MN: University of Minnesota Press.

Fulmer, C. A., and Gelfand, M.J. 2012. At what level (and in whom) we trust: Trust across multiple organizational levels. Journal of Management, 38(4): 1167-1230.

Gabriel, Y. 1991. Turning facts into stories and stories into facts: A hermeneutic exploration of organizational folklore. Human Relations, 44(8): 857-875.

Gabriel, Y. 1995. The unmanaged organization: stories, fantasies and subjectivity. Organization Studies, (16): 477-502.

Gabriel, Y. 1997. Meeting God: When organizational members come face to face with the supreme leader. Human Relations, 50(4): 315-346.

Gabriel, Y. 1998. The use of stories. In Symon, G. and Cassell, C. (Eds.), Qualitative methods and analysis in organizational research. London: Sage, 135-160.

Gabriel, Y. 2000 Storytelling in organizations. New York: Oxford University Press.

Gillespie, N., and Dietz, G. 2009. Trust repair after an organization-level failure. Academy of Management Review, 34(1): 127-145.

Glaser, B.G. 1978. Theoretical sensitivity. Advances in the methodology of grounded theory. Mill Valley, California: Sociology Press.

Grey, C., and Garsten, C. 2001. Trust, control and post-bureaucracy. Organization Studies, 22(2): 229-250.

Groarke, S. 2002. Psychoanalysis and structuration theory: The social logic of identity. Sociology, 36(3): 559-576. 
Harding, N. 2007. On Lacan and the becoming-ness of organizations/selves. Organization Studies, 28(11): 1761-1773.

Hardy, C. 2001. Researching organizational discourse. International Journal of Management \& Organization, 31(3), 25-48.

Henderson, S., and Gilding, M. 2004. 'I've never clicked this much with anyone in my life': Trust and hyperpersonal communication in online friendships. New Media \& Society, 6(4): 487506.

Hendry, P.M. 2007. The future of narrative. Qualitative Inquiry, 13(4): 487-498.

Hoedemakers, C. and Keegan, A. 2010. Performance pinned down: Studying subjectivity and the language of performance. Organization Studies, 31(8): 1021-1044.

Hoegh, D.G., and Bourgeois, M.J. 2002. Prelude and postlude to the self: Correlates of achieved identity. Youth \& Society, 33(4): 573-594.

Hosmer, L.T. 1995. Trust: The connecting link between organizational theory and philosophical ethics. Academy of Management Review, 20(2): 379-403.

Johnson, R., Gudmand-Hoyer, M. 2010. Lacan and the lack of humanity in HRM. Organization, 17(3): 331-344.

Jokinen, E. 2004. The makings of mother in diary narratives. Qualitative Inquiry, 10(3): 339359.

Keyton, J. and Smith, F.L. 2009. Distrust in leaders: Dimensions, patterns, and emotional intensity. Journal of Leadership \& Organizational Studies, 16(1): 6-18.

Lacan, J. 1977. The four fundamental concepts of psychoanalysis. London: Hoghart Press.

Lacan, J. 1988. The seminar of Jacques Lacan, Book II: The ego in Freud's theory and in the technique of psychoanalysis 1954-1955. New York: Norton.

Langfred, C.W. 2004. Too much of a good thing? The negative effects of high trust and individual autonomy in self-managing teams. Academy of Management Journal, 47(3): 385-399.

Lewicki, R.J., Tomlinson, E.C., and Gillespie, N. 2006. Models of interpersonal trust development: Theoretical approaches, empirical evidence, and future directions. Journal of Management, 32(6): 991-1022.

Li, P.P. 2011. The rigour-relevance balance for engaged scholarship: New frame and new agenda for trust research and beyond. Journal of Trust Research, 1(1): 1-21.

Maguire, S., and Phillips, N. 2008. 'Citibankers' at Citigroup: A study of the loss of trust after a merger. Journal of Management Studies, 45(2): 372-401. 
Maguire, S., Phillips, N., and Hardy, C. 2001. When 'silence = death', keep talking: Trust, control and the discursive construction of identity in the Canadian HIV/AIDS treatment domain. Organization Studies, 22(2): 285-310.

Mayer, R., and Davis, J.H. 1999. The effect of the performance appraisal system on trust for management: A field quasi-experiment. Journal of Applied Psychology, 84(1): 123-136.

McEvily, B., Perrone, V., and Zaheer, A. 2003. Trust as organizing principle. Organization Science, 14(1): 91-103.

Morison, T. and Macleod, C. 2013. A performative-performance analytical approach: Infusing Butlerian theory into the narrative-discursive method. Qualitative Inquiry, 19(8): 566-577.

Norman, S.M., Avolio, B.J., and Luthans, F. 2010. The impact of positivity and transparency on trust in leaders and their perceived effectiveness. The Leadership Quarterly, 21: 350-364.

Ollerenshaw, J. and Creswell, J.W. 2002. Narrative research: A comparison of two restorying data analysis approaches. Qualitative Inquiry, 8(3): 329-347.

Parker, I. 2005. Lacanian discourse analysis in psychology. Theory \& Psychology, 15(2): 163182.

Parker, I. 2010. Psychosocial studies: Lacanian discourse analysis negotiating interview text. Psychoanalysis, Culture \& Society, 15(2): 156-172.

Polikinghorne, D.E. 2007. Validity issues in narrative research. Qualitative Inquiry, 13(4): 471486.

Ragland, E. 1996. An overview of the real, with examples from seminar I. In Feldstein, R., Fink, B., and Jaanus, M. (Eds.) Reading seminars I and II: Lacan's return to Freud. Albany, NY: State University of New York: 192-211.

Reed, M. I. 2001. Organization, trust and control: A realist analysis. Organization Studies, 22(2): 201-228.

Roberts, J. 2005. The power of the 'imaginary’ in disciplinary processes. Organization, 12(5): 621-645.

Rogan, A.I. and De Kock, D. M. 2005. Chronicles from the classroom: Making sense of the methodology and methods of narrative analysis. Qualitative Inquiry, 11(4): 628-649.

Rousseau, D.M., Sitkin, S.B, Burt, R.S., and Camerer, C. 1998. Not so different after all: A cross-discipline view of trust. Academy of Management Review, 23(3): 393-404. 
Schoorman, F.D., Mayer, R.C., and Davis, J.H. 2007. An integrative model of organizational trust: Past, present and future. Academy of Management Review, 32(2): 344-354.

Sermijn, J., Devlieger, P. and Loots, G. 2008. The narrative construction of the self: Selfhood as a rhizomatic story. Qualitative Inquiry, 14(4): 632-650.

Sievers, B. 2003. Against all reason: Trusting in trust. Organizational \& Social Dynamics, 3(1): 19-39.

Six, F., and Skinner, D. 2010. Managing trust and trouble in interpersonal work relationships: Evidence from two Dutch organizations. The International Journal of Human Resource Management, 21(1-3): 109-124.

Skinner, D., Dietz, G. and Weibel, A. The dark side of trust: When trust becomes a 'poisoned chalice'. Organization, 21(2): 206-224.

Stavrakakis, Y. 2008. Subjectivity and organized other: Between symbolic authority and fantasmatic enjoyment. Organization Studies, 29(7): 1037-1059.

Sveningsson, S. and Alvesson, M. 2003. Managing managerial identities: Organizational fragmentation, discourse and identity struggle. Human Relations, 56(10): 1163-1193.

Terrion, J.L., and Ashforth, B.E. 2002. From 'I' to 'we': The role of putdown humor and identity in the development of a temporary group. Human Relations, 55(1): 55-88.

Tomlinson, E.C., and Mayer, R.C. 2009. The role of causal attribution dimensions in trust repair. Academy of Management Review, 34(1): 85-104.

Van der Zee, K., Vos, M., and Luijters, K. 2009. Social identity patterns and trust in demographically diverse work teams. Social Science Information, 48(2): 175-198.

Vanheule, S., Lievrouw, A. and Verhaeghe, P. 2003. Burnout and intersubjectivity: A psychoanalytical study from a Lacanian perspective. Human Relations, 56(3): 321-338.

Webb, J. 2004. Organizations, self-identities and the new economy. Sociology, 38(4): 719-738.

Wolgemuth, J.R. and Donohue, R. 2006. Toward an inquiry of discomfort: Guiding transformation in ‘emancipatory’ narrative research. Qualitative Inquiry, 12(5): 1022-1039.

Ybema, S., Keenoy, T., Oswick, C., Beverungen, A., Ellis, N. and Sabelis, I. 2009. Articulating identities. Human Relations, 62(3): 299-322.

Zhang, Y., and Huxham, C. 2009. Identity construction and trust building in developing international collaborations. Journal of Applied Behavioral Science, 45(2): 186-211. 